\title{
Chapter 14 \\ Climate-Induced Challenges \\ for Wetlands: Revealing the Background \\ for the Adaptive Ecosystem Management in the Biebrza Valley, Poland
}

\author{
Mateusz Grygoruk, Urszula Biereżnoj-Bazille, Michał Mazgajski, \\ and Jadwiga Sienkiewicz
}

\subsection{Introduction}

Although climate change has already been recognised as a challenge for European wetlands, with regard to their hydrology (Acreman 2012; Okruszko et al. 2011; Winter 2000), ecology (Keddy 2010), agriculture (Hardig et al. 1997) and even tourism (Wall 1998), the management of protected wetlands still faces a fusion of problems regarding the definition and implementation of effective, climate-changeorientated conservation and adaptation strategies. In cases of broad wetlands, such as the Biebrza Valley (NE Poland; Fig. 14.1), environmental and socio-economic management problems are often related to hydrological processes and a chain reaction of ecosystems and stakeholders to (climate-change induced) the temporal alteration of groundwater levels, flood frequency and duration of regular floods and their volume (Schneider et al. 2011). Those hydrological factors strongly depend on

\footnotetext{
M. Grygoruk $(\bowtie)$

Department of Hydraulic Engineering, Warsaw University of Life Sciences, ul. Nowoursynowska 159, 02-776 Warsaw, Poland

Biebrza National Park, Osowiec-Twierdza 8, 19-110 Goniądz, Poland

e-mail: m.grygoruk@levis.sggw.pl

U. Biereżnoj-Bazille

Institute of Biology, University of Białystok, ul. Świerkowa 20B, 15-950 Białystok, Poland

Biebrza National Park, Osowiec-Twierdza 8, 19-110 Goniądz, Poland

e-mail: ubiereznoj@biebrza.org.pl

M. Mazgajski

Division of the Measurement and Observation Service in Warsaw, Institute of Meteorology and Water Management, ul. Podleśna 61, 01-673 Warsaw, Poland

e-mail: michal.mazgajski@imgw.pl

J. Sienkiewicz

Department of Nature and Landscape Conservation, Institute of Environmental Protection - National Research Institute, ul. Krucza 5/11d, 00-548 Warsaw, Poland e-mail: sienkiewicz@ios.edu.pl
} 


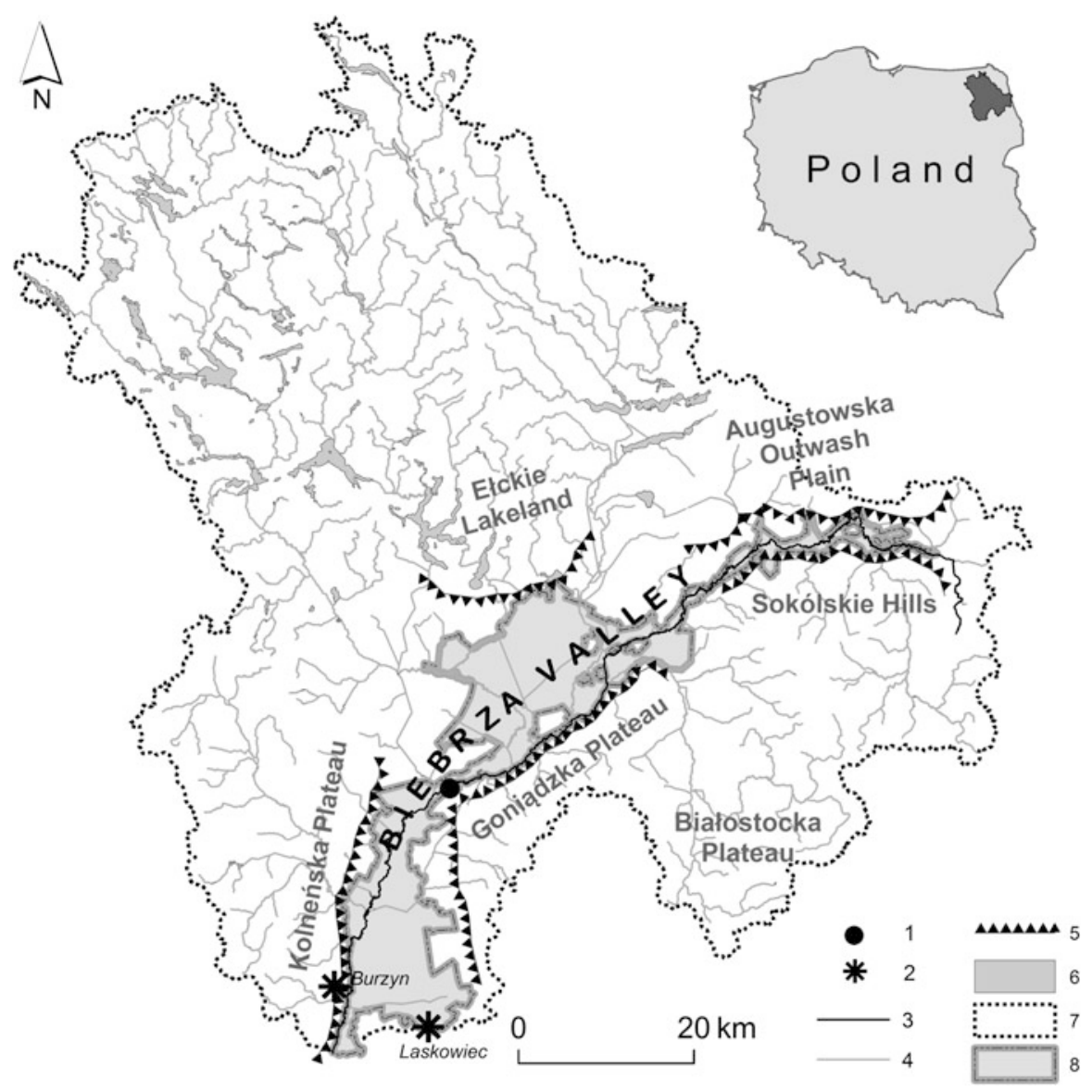

Fig. 14.1 Geomorphologic outline of the Biebrza catchment and Biebrza Valley: 1 - water gauge Osowiec on Biebrza, 2 - rain gauges, 3 - River Biebrza, 4 - rivers and canals - Biebrza tributaries, 5 - boundaries of the Biebrza Valley, 6 - lakes, 7 - Biebrza catchment, 8 - boundaries of the Biebrza National Park

both long- and short-term climatic fluctuations, of which the most important is the temporal distribution of precipitation responsible for runoff dynamics and air temperature variability, which determines snow accumulation, snowmelt and evapotranspiration.

The complexity of hydrological processes and their spatial relations within the Biebrza Valley induced the development of various types of wetland: minerotrophic calcareous fens, regularly flooded riparian marshes and ombrotrophic bogs (Okruszko 1991; Oświt 1991; Wassen et al. 2006). In many parts of the analysed area the status of wetlands can be considered as near-natural, because they evolve within the feedback of natural, physical and ecological processes, not being directly influenced by any type of water management nor agricultural pressures (Grygoruk et al. 2011a; Wassen et al. 1990). Therefore, one of the most important, trans-national, European value of 
the Biebrza Wetlands is the fact that they are considered a representative reference for wetland restoration (Wassen et al. 2002). To protect this valuable geoecosystem, the Biebrza National Park (BNP) was founded in 1993. Since then, almost 60,000 ha of unique wetland habitats have been covered by protection of the highest national priority. Despite that, more than $40 \%$ of the area of BNP remains privately-owned. Therefore, along with environmental conservation priorities, stakeholder pressures aimed at the intensification of agriculture polarises the goals of wetland management in the Biebrza Valley. The dominant demands of stakeholders are aimed at increasing agricultural production (haymaking) and draining the wetlands. This would entail a dramatic loss of biodiversity and deterioration in wetland habitats. The drainage pressure has increased in the last few years of the first decade of the twenty-first century, when extreme weather conditions (heavy rainfall in the summer, extensive droughts in the autumn and frosty winters) entailed summer flooding, which - while formerly rare - became a frequent obstacle to agriculture. Thus, not only has the primary impact of climate change (hydrological processes alteration due to climate change) recently appeared as a challenge for wetland ecosystems in the Biebrza Valley, but also this secondary impact (considered as a climate-change-induced stakeholder pressure) became an aspect to be widely-discussed in the preparation and application of appropriate management strategies for the BNP. Hence, wishing to establish an appropriate diagnosis of the Biebrza Wetlands' functioning in regard to contemporary and prospective habitat dynamics and facing increasing stakeholder pressures, special emphasis should be given to a long-term temporal analysis of the hydrology and climate of the Biebrza Valley.

The implementation of the HABIT-CHANGE project ("Adaptive management of climate-induced changes of habitat diversity in protected areas"), started in 2010, allowed the establishment of an international, interdisciplinary analytical approach to potential challenges for the environment and their socio-economic aspects induced by climate change. This study, by considering the climate-induced impacts on wetlands and stakeholders, presents the most important results of the project's implementation in the BNP. Although some general analysis on temporal variability of hydrometeorological phenomena were considered by Grygoruk et al. (2011b), Ignar et al. (2011), Kossowska-Cezak (1984), Kossowska-Cezak et al. (1991), Maksymiuk (2009) and Maksymiuk et al. (2008), the context of climate change in ecosystem management and habitat development in the Biebrza Valley has so far not been considered in the literature. Therefore, this chapter becomes the first step towards a measurable estimation of the challenges, which come along with both the so far observed and projected climate change impacts, to wetland ecosystem management in the Biebrza Valley.

The main aim of this chapter is to provide elementary information on climateinduced challenges for ecosystems and stakeholders of wetlands in the Biebrza Valley. In the first part of this chapter, we analyse hydro-meteorological phenomena recorded in the Biebrza Valley within the years 1970-2011 (with respect to the precipitation analysis) and 1951-2011 (in order to define flooding frequency and temporal dynamics). In the next step, we analyse the projected climate change for the Biebrza Valley in the time horizon 2070-2100 on the basis of ten different 
ensembles of Global Circulation Models-Regional Climate Models (GCM-RCM) combined with the SRES A1B emission scenario. On the basis of the GCM-RCM projections on temperature and precipitation changes, we set up two hypothetical scenarios to be analysed in the context of climate-change related challenges for habitats, and also for the socio-economic development of the Biebrza Valley. In the last section of the chapter we discuss the interface between the potential environmental conservation of valuable wetland habitats and the management pressures of various groups of stakeholders. Concise conclusions from our research are highlighted in the last part of this chapter.

\subsection{Environment and Management of the Biebrza Valley}

Biebrza Valley and its wetlands have become a sink of the catchment of the River Biebrza, which covers $7,120 \mathrm{~km}^{2}$, (almost $2.5 \%$ of the total area of Poland). Surrounded by glacial plateaus of the Wartian (Riss) Glaciation (Goniadzka and Kolneńska Plateau, Sokólskie Hills) and morphologic units of the Vistulian (Wurm) Glaciation (Ełckie Lakeland and Augustowska Outwash Plain), the ice marginal valley of Biebrza (Fig. 15.1) is one of the largest coherent wetland areas in Central Europe. The majority of the valley is covered with peat (locally decently decomposed due to former drainage), which rests on the sandy plain of the Biebrza Ice Marginal Valley. The maximum thickness of the peat layer reaches from approximately $3 \mathrm{~m}$ in the southern-most part of the valley, up to approximately $8 \mathrm{~m}$ in the northern part, in the so-called Upper Basin (Żurek 1984). Locally, the continuous peat cover is perforated by sandy dunes, which play an important role in sustaining the biodiversity of the wetlands. The temperate climate of the Biebrza Valley with continental influences can be characterised by the average annual air temperature of $6.6^{\circ} \mathrm{C}$ (Banaszuk 2004), with annual magnitudes of more than $55^{\circ} \mathrm{C}$ (maximum and minimum values of air temperature measured in the Biebrza Valley in 2011 reached $30.5{ }^{\circ} \mathrm{C}$ and $-25.6{ }^{\circ} \mathrm{C}$, respectively). The average annual sum of precipitation calculated by Kossowska-Cezak (1984) for the Biebrza Valley equals $583 \mathrm{~mm}$. On the basis of precipitation measurements in the Laskowiec rain gauge (see Fig. 15.1) for the years 1996-2011, we estimate an average annual sum of precipitation of $574 \mathrm{~mm}$. The average sum of precipitation in the summer (May-August) - a critical season for wetlands due to the high rate of evapotranspiration - equals $260 \mathrm{~mm}$ (data from the Laskowiec rain gauge). The constant saturation of the valley, preconditioned by the hydrogeology and low slopes, occasions the appropriate conditions for valuable wetland habitats and species. Among the most important wetland habitats in the Biebrza Valley, there are alkaline fens, mire meadows, transition mires and bogs with pine bog forest and alder forests. All are listed in Annex I of the 92/43/EEC "Habitat Directive". Due to presence of unique plant species (e.g. Saxifraga hirculus, Liparis loeselii, Polemonium coeruleum, Swertia perennis, Betula humilis), those habitats have become those of the highest ecological value and consequently of the highest conservation status. The exceptionally rich fauna of the Biebrza Valley is represented by 
numerous, rare wetland birds (e.g. Acrocephalus paludicola, Aquila clanga, Grus grus and Philomachus pugnax), mammals (e.g. Alces alces, Canis lupus, Lynx lynx), fish (e.g. Rhodeus sericeus, Aspius aspius, Cobitis taenia) and invertebrates (e.g. Parnassius mnemosyne). The majority of habitats and species of the Biebrza Wetlands are determined by hydrological processes (groundwater level, soil saturation, flooding and inundation). Therefore, Wagner and Förster (2011), using the algorithm of habitat sensitivity assessment for climate change provided by Petermann et al. (2007), reported on the high general sensitivity of wetland habitats in the Biebrza Valley to possible climate change. For more details on the environmental features of the Biebrza Valley the reader is referred to Banaszuk (2004), Wassen et al. (2006) or the numerous other scientific publications regarding the ecology of the Biebrza Wetlands.

Due to the complex structure of land possession and the fact that approximately $40 \%$ of the area of the BNP remains privately owned, a vast share of the wetlands is agriculturally managed. Agricultural use of the area is dominated by extensive meadow mowing and - seldom - pasture grazing. Due to exceptional environmental value of the Biebrza Valley, most of the agricultural activities, such as haymaking, are supported by agro-environmental schemes and direct agricultural subsidies, co-financed by the European Union.

With regard to the agricultural management of the Biebrza Valley, especially within the BNP, numerous conflicts arose on the interface of environmental conservation and agricultural management. Conflicts are related to the necessity of meadow drainage claimed by farmers and local authorities. The pressure of local stakeholders has escalated in years, when the amount of precipitation in the summer exceed average values (such as in the years 2010 and 2011, when the sum of precipitation recorded in the period May-August reached $377 \mathrm{~mm}$ and $398 \mathrm{~mm}$, respectively). Moreover, the fact, that the River Biebrza receives the outflow from the whole catchment, underpins even more water-related problems, as the water levels in Biebrza and its tributaries in the river valley are controlled by water management in the upper parts of the catchment. Large-scale modelling studies conducted in NE Poland revealed that the climate change-induced outflow variability should be considered at catchment scale (Piniewski et al. 2012). Hence, in order to derive climate-adapted management strategies for the Biebrza Wetlands, the analysis should concern the spatial scale of the whole catchment and include all the stakeholders that are involved in water management.

\subsection{Climate Change in the Biebrza Valley}

\subsubsection{Observations}

Among the hydrological processes that induce the function and state of the wetlands in the Biebrza Valley, precipitation (sums and temporal distribution) and flooding 
(frequency and temporal distribution) appear the most important. In this regard, temporal variability of precipitation and flood dynamics were analysed in order to search for possible trends that can be brought about by climate change.

Analysis of precipitation in the Biebrza Valley was done on the basis of data recorded in rain gauges located in Laskowiec (1996-2011 dataset) and Burzyn (1970-2010) (see location on the Fig. 14.1). Flood analysis was done on the basis of discharge data for the River Biebrza in Osowiec in the years 1951-2011. The flood threshold of river discharge (bankful flow) was set up on the basis of multi-year observations as $25 \mathrm{~m}^{3} / \mathrm{s}$ (Grygoruk et al. 2011b). Also the largest floods (over the threshold of the median of the highest annual discharges of Biebrza in Osowiec: $\mathrm{Q}>84.1 \mathrm{~m}^{3} / \mathrm{s}$, which is a flood of $50 \%$ exceedence frequency) were analysed in order to reveal the temporal dynamics of flooding in particular seasons. Those sizeable floods are important from an ecological point of view, as they cover a large extent of the valley and induce the development and function of riparian zones as well as a network of ox-bow lakes, entailing water exchange between the river and a large share of the floodplain.

Temporal variability in amounts of precipitation recorded in the Burzyn rain gauge during hydrological "summer" (May-October) and "winter" (November-April) was analysed for each particular year (Fig. 14.2a), as well as the ratio of winter to summer precipitation (Fig. 14.2b). A slightly decreasing trend in summer volumes of precipitation within the years 1970-2010 can be observed, along with the considerable trend in increasing winter precipitation. One can conclude that the share of precipitation in the cold part of the year increases in the total amount of annual precipitation. However, a vast increase in rainfall intensity in the summer can be observed (Fig. 14.2c) although in general summers seem to be drier, the increasing temporal concentration of precipitation entails possible flooding and remains a challenge for management and ecosystems. This observation confirms the results of Liszewska and Osuch (2000), who stated that more extreme weather conditions can occur as a major consequence of climate change in Central Europe. Similar results for the analysis of precipitation data recorded in the climate monitoring station of the IMGW (Institute of Meteorology and Water Management) in Białystok (50 km from the Biebrza Valley), in the years 1971-2010, were observed by Grygoruk et al. (2011a). Hence, the precipitation dynamics and their temporal distribution analysed herein on the basis of data from the Laskowiec and Burzyn rain gauges most likely reflect the long-term regional trend.

The increasing temporal concentration and intensity of summer sums of rainfall correspond with the results of temporal analysis of the largest floods (Fig. 14.2e). It indicates a significant increase in summer flooding in the first decade of the twentyfirst century, compared to the second half of the twentieth century. Also, the total volume of individual summer floods (calculated as the amount of water momentary stored in the Lower Biebrza Basin during the flood events; Fig. 14.2f) increased in the last 15 years. Temporal analysis of snowmelt floods in the Biebrza Valley (Fig. 14.2d) indicates the continuing trend of the earlier occurrences of floods in 1950-2012. The analysis of the start of the spring flood was emphasised since this process induces the ecosystem services of marshes, such as their role in strictly temporal fish spawning and nutrient removal (Okruszko et al. 2011). It was 

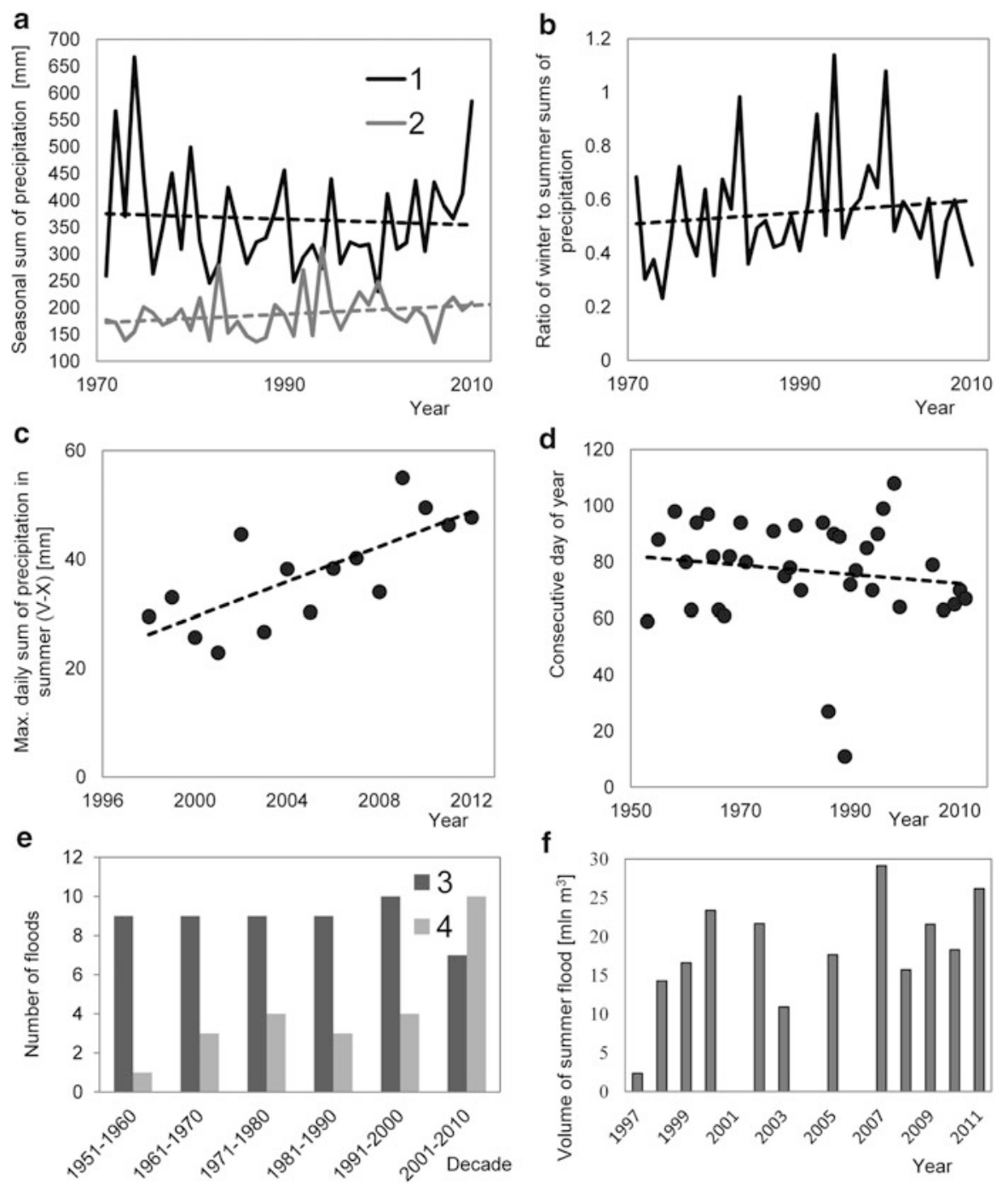

Fig. 14.2 Climate variability indicators recorded in the Biebrza Valley: (a) seasonal sums of precipitation recorded in Burzyn rain gauge: 1 - summer (May-October); 2 - winter (NovemberApril); (b) annual ratios of winter and summer sums of precipitation; (c) maximum daily sums of precipitation in summer (May-October), (d) day of the start of the snowmelt flood calculated for floods; (e) number of floods $\left(\mathrm{Q}>\mathrm{Q}_{50 \%}\right)$ recorded in Osowiec water gauge, 3 - winter (November-April), 4 - summer (May-October); (f) total volumes of summer floods in the Lower Biebrza Basin (based on the Burzyn gauge). Dashed lines present general trends (Source of data: Institute of Meteorology and Water Management (IMGW))

recognised that over the time scale 1951-2011, the average day of the start of the spring flood moved earlier by about 10 days (Fig. 14.2d). Such an observation, combined with the results presented by Ignar et al. (2011) who revealed the 
decreasing trend in flood volume in the Biebrza Valley within the period 1961-2000, permits the assumption that the climate-induced changes in spring flood dynamics has become an issue in ecosystem continuity and function (especially for water-dependent terrestrial habitats of marshes and for fish species). This fact, which can partly remain controlled by water management in the upper parts of the Biebrza catchment, is suspected to be the main challenge for migratory birds such as geese, which are strongly dependent on the flood occurrence and extent (Polakowski et al. 2011). The earlier appearance of floods along with the decreasing volume of the flood wave limit the extent of fish spawning and induce an increasing in-situ fertilisation of meadows with the remains of vegetation and nutrients from previous seasons. Variability in the spring flood dynamics is of minor importance to agriculture, as field activities such as haymaking start later, once the spring flood has finished (May-June). Contradictorily, the changing dynamics of summer floods remain a challenge for both the agricultural maintenance of wetlands and ecosystems, remaining the most significant climate-related pressure on ecosystems and management for wetlands in the Biebrza Valley.

The analysis of precipitation and flood dynamics in the Biebrza Valley leads to the general conclusion that (1) during the analysed period of 1970-2010 the share of summer precipitation in the annual sum of precipitation has decreased, (2) maximum daily volumes of precipitation have increased, which expresses the increasing frequency of extreme precipitation events, (3) significant increase in sizeable summer floods occurrence $\left(\mathrm{Q}>84.1 \mathrm{~m}^{3} / \mathrm{s}\right)$ was reported in the period 2001-2011 compared to the years 1951-2000, and (4) the regular spring floods in the Biebrza Valley start under average contemporary conditions approximately 10 days earlier than in the 1950 s.

\subsubsection{Projections}

As some visible trends in precipitation dynamics and flooding in the Biebrza Valley were observed (Fig. 14.2), the next step of our research was to establish and assess prospective climate change projections for the Biebrza Wetlands. Climate change data for the Biebrza Valley was derived from the ENSEMBLES project results (van den Linden and Mitchell 2009; after Stagl and Hattermann 2011). There were ten different GCM-RCM combinations for the SRES A1B emission scenario considered with regard to climate change impact analysis in the Biebrza Valley: HadCM3-C4I/ RCA3, CNRM/Arpege-DMI/HIRHAM5, ECHAM5-DMI/HIRHAM5, HadCM3ETHZ/CLM3.21, HadCm3Q0-HC/HadRM3Q0, HadCM3Q16-HC/HadRM3Q16, HadCm3Q3-HC/HadRM3Q3, ECHAM5-ICTP/REGCM3, BCM-SMHI/RCA3 and HadCM3Q3-SMHI/RCA3. Prospective relative changes in monthly sums of precipitation $[\mathrm{P} ; \mathrm{mm}]$ and average monthly air temperatures $\left[\mathrm{T} ;{ }^{\circ} \mathrm{C}\right]$ in the time horizon 2070-2100 were referred to the values of average monthly temperature and precipitation recorded at the Laskowiec monitoring station of the BNP (see Fig. 14.1) in the years 2000-2011. As ten different GCM-RCM-emission scenario combinations were 

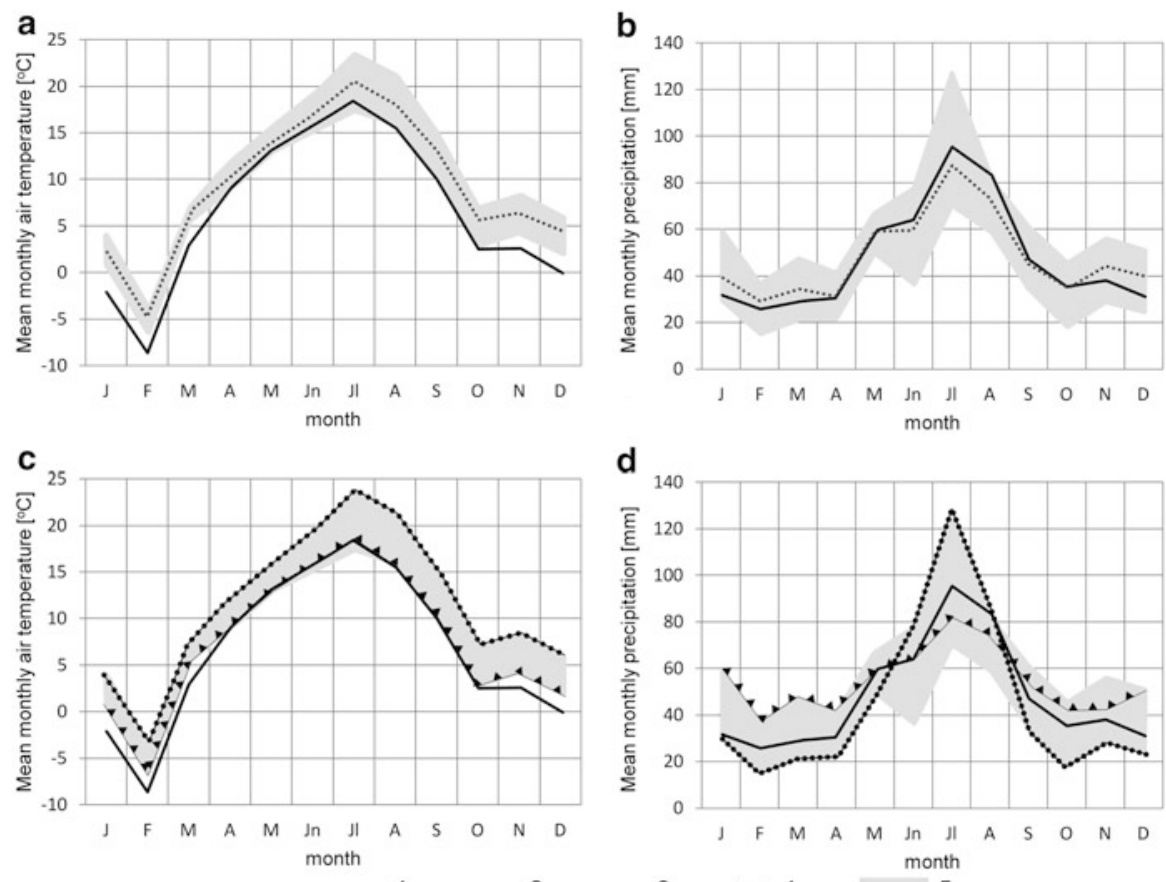

Fig. 14.3 Climate change projections for the Biebrza Valley and hypothetical "mild" and "extreme" climate change scenarios (time horizon 2070-2100); (a) comparison of prospective changes in mean monthly air temperature referred to the present conditions, (b) comparison of prospective changes in mean monthly precipitation referred to the present conditions, (c) "mild" and "extreme" scenarios of mean monthly temperature changes referred to the present conditions, (d) "mild" and "extreme" scenarios of the mean monthly precipitation changes referred to the present conditions. 1 - present conditions (2000-2012), 2 - average values of all analysed climate change projections for SRES A1B greenhouse emission scenario, 3 - hypothetical "extreme" scenario for the Biebrza Valley; 4 - hypothetical "mild" scenario for the Biebrza Valley, 5 - uncertainty range

considered in prospective climate change analysis, potential future changes of $\mathrm{P}$ and $\mathrm{T}$ in particular months in time horizon 2070-2100 varied in the range $17-57 \mathrm{~mm}$ in the case of the average monthly sum of precipitation, and from 1.2 up to $5.8^{\circ} \mathrm{C}$ in the case of the average monthly air temperature. Lower and upper extreme projections derived from the GCM-RCM's analysed for each particular month were considered for the purpose of this study as the boundaries of the projection's uncertainty range (Fig. 14.3a-d). In other words, the uncertainty range of prospective changes in $\mathrm{P}$ and $\mathrm{T}$ in the Biebrza Valley can be considered as a most probable range of climate change dimensions predicted with the analysed GCM-RCM and emission scenarios combinations.

Among the GCM-RCM-emission scenarios ensembles analysed for the Biebrza Valley, a general increase in average monthly air temperature is projected (Fig. 15.3a). Throughout the whole prospective average year in 2070-2100, the 
projected mean monthly air temperature is higher in the case of every month than that observed in 2000-2011. The biggest absolute differences between projected and contemporary observed monthly average air temperatures were defined for the Biebrza Valley for autumn and winter (October-January), whereas the smallest differences are projected for late spring (April-June).

Prospective alterations in monthly sums of precipitation derived from the analysed GCM-RCM's do not present such a clear direction of changes as the values of average monthly air temperature. However, a similar trend in precipitation increase in the winter months (November-January) can be seen (Fig. 14.3b), whereas the mean values of projected monthly sums of precipitation in the summer, projected for the time horizon 2070-2100, are slightly lower than the values observed in 2000-2011. However, the relatively wide range of uncertainty (herein referred to as the difference between the highest and the lowest prospective monthly sum of precipitation) does not allow the assumption as to whether the temporal rainfall distribution presents any unquestionable pattern.

Comprehensive analysis of observed and prospective trends in $\mathrm{P}$ and $\mathrm{T}$ quantitative variability revealed that in the time horizon 2070-2100: (1) the ongoing decrease in summer sums of precipitation will continue, (2) extreme rainfall events in the summer with increased frequency will occur, and (3) the average monthly air temperature is likely to increase, especially in winter months. Hence, it is suspected that the valuable ecosystems and wetland management in the Biebrza Valley will face a decreasing frequency of spring flooding (prospective increase of air temperature in the winter will induce a reduction in snow accumulation and consequently snowmelt flooding will be reduced). Moreover, an increasing frequency in summer flooding, with any possibility, will underpin an escalation of conflicts at the interface of environmental conservation and agricultural management, as with any likelihood the pressure on meadow drainage will increase. Moreover, it is likely that due to the general increase in air temperature, the potential evapotranspiration intensity will also increase. Thus, the water balance of wetlands in the Biebrza Valley may be affected and hydrological stress on the vegetation due to a lack of water in the soil can occur (Stagl and Hattermann 2011).

\subsection{Climate-Induced Challenges for Adaptive Management - The Burning Interface of Habitats and Stakeholders}

\subsubsection{Mild vs. Extreme}

As identified, adaptation strategies in the environmental conservation of wetlands in the Biebrza Valley in its agricultural context have to consider the observed and prospective trends in climate variability. The range of uncertainty of projected $\mathrm{P}$ and T changes (Fig. 14.3) permits two hypothetical scenarios to be derived - "mild" 
and "extreme", which can roughly be interpreted as the most positive and the most negative projections of $\mathrm{P}$ and $\mathrm{T}$ changes among the herein analysed GCM-RCMESs. Both "mild" and "extreme" scenarios were further analysed in order to define possible positive and negative climate change impacts on components of the environment in the Biebrza Valley, as well as for the socio-economic aspects of wetland management. Due to the reported and widely-discussed uncertainty of GCMs and RCMs (e.g. Anagnostopoulos et al. 2010; Kundzewicz and Stakhiv 2010; Wilby 2005, 2010), the authors of this paper state that the results presented herein on prospective climate change (including hypothetical "mild" and "extreme" scenarios) should not be considered as forecasts, but as a scientifically and statistically-based background for the analysis of possible, climate-induced impacts on environmental and socio-economic aspects of the Biebrza Valley.

The "mild" scenario (Fig. 14.3c, d) was derived in order to represent the most positive prospective climate change for the contemporary environment of the Biebrza Valley. The temporal variability in air temperature and precipitation provided in this scenario entails the sustainability of riparian ecosystems. The lowest possible increase in the air temperature during winter months (November-March) will sustain snow accumulation, which - along with an increased winter sum of precipitation - would underpin respectable spring flooding. Hence, nutrient removal from the floodplain, as one of the main ecosystem services of riparian wetlands (Maltby 2009), will also be sustained. Satisfactory and regular spring flooding would also entail appropriate fish spawning (e.g. in the case of the European pike Esox lucius whose spawning season occurs in March-April) and provide suitable conditions for migratory wetland birds such as geese (Anserinae), ducks (Anatinae), ruffs (Philomachus pugnax) and various waders (Scolopacidae and Tringinae). For the remaining part of the average year in the "mild" scenario of climate change, the air temperature will remain slightly higher than the average for contemporary conditions. Precipitation volumes and rainfall temporal distributions defined in this scenario assume a significant increase in the cold part of the year and a slight decrease in the summer. Though, in this way, the possibility of sizeable summer floods is likely to be reduced. Thus, the stakeholders' pressure on ecosystems by demanding intensive drainage will also be lowered. However, as none of the information on the temporal distribution of precipitation could have been derived from the analysed GCM-RCM ensembles, it is fairly possible that summer flooding in the Biebrza Valley in the "mild" scenario can still be an important management challenge in 2070-2100, if the observed increasing trend in maximum daily precipitation (Fig. 14.2c) persisted.

The "Extreme" scenario (see Fig. $14.3 \mathrm{c}$, d) was established to represent the most challenging conditions for the environment and management of the Biebrza Valley. It assumes the highest increase in the average monthly temperature among the entire set of GCM-RCM projections analysed, which is $4.1^{\circ} \mathrm{C}$ in the scale of the average year in the period 2070-2100. The most significant increase in air temperature (up to $5.2{ }^{\circ} \mathrm{C}$ ) was projected for the winter (December-March) and for the peak of summer (July) (Fig. 14.3c). A more polarised temporal distribution of the average monthly sums of precipitation was assumed in the "extreme" scenario. 
Although the annual sum of precipitation was projected to remain almost equal to contemporary conditions, a vast reduction in precipitation in the winter (and consequently snow cover) (November-March), extensive droughts in spring (April-May), extremely wet summers (June-August) and extremely dry autumns (September) were hypothetically assumed in the "extreme" scenario on the basis of the uncertainty range of analysed GCMs-RCMs. Under these hypothetical conditions one can expect (1) sizeable summer flooding, (2) no snow accumulation and consequently a significantly reduced volume and extent of spring floods, and (3) serious droughts in the spring and autumn. As discussed in the case of the hypothetical "mild" scenario, fish, birds and plant associations of the Biebrza Valley will critically face hypothetical impacts of the "extreme" climate scenario even more, as most of the key environmental factors (flooding and (over)availability of water) are likely to be significantly altered. Hence, without a doubt, the longterm environmental conservation strategies of the BNP, in order to reach their environmental goals, will have to consider the climatic impacts on ecosystems and adapt to climate change.

\subsubsection{Legislative Context of Environmental Management in the Biebrza Valley}

Despite the fact that the environmental management of Polish national parks ought to be established in long-term "Protection Plans" (PPs) (Pol.: Plany Ochrony), contemporary environmental management measures implemented by the BNP (and numerous other national parks in Poland) are based on so-called "Management Objectives" (Minister of the Environment 2011). MOs become a short-term management strategy, proposed each 2 years by the national park's management, approved by scientists and authorised by the Minister of the Environment. MOs are substitutes for PPs, as the legislative context of PPs requires long-term procedures. In the case of many national parks in Poland the PPs' enhancement process is ongoing. PPs - in contrast to MOs - have to be approved by a broad audience of stakeholders (e.g. local authorities, NGOs) before they are signed by the Minister of the Environment, and therefore become much more complex and long-term management strategies. As MOs are renewed every 2 years, the management goals and measures are being (or can be) continuously verified and adjusted to current conditions and circumstances. In this regard, the environmental management implemented by the BNP can be considered "adaptive", as it (potentially) anticipates dynamic changes in particular elements of the wetland's ecosystems (Grumbine 1994; Lee 1991). On the other hand, due to the short-term set up, MOs of the BNP do not consider climate change as a driving force, which potentially induces a dynamic state of ecosystems. Moreover, contemporary stakeholder pressures that occur within the Biebrza Valley (intensification of agriculture, drainage of wetlands), although partly anticipated by the MOs, also have so far not 
been considered climate change-related. Therefore, although the environmental management, which is currently implemented by the BNP can be considered as adaptive, it does not emphasise the transient influence of climate. Hence, it cannot be considered climate-adapted.

\subsubsection{Qualitative Impact Assessment and Stakeholder Context of Adaptive Management}

Once the prospective climate-induced challenges for the Biebrza Valley were defined, then in order proceed with the first step towards the establishment of a climate-adapted management plan for the BNP, the qualitative assessment of selected, direct and indirect climate-related impacts on selected plant associations was carried out (Table 14.1). It should be stated that only selected plant associations have been analysed; in order to perform a comprehensive assessment of the ecosystem's response the whole set of species (including invertebrates, fish, birds and mammals) needs to be included. However, such an approach would have to be based on detailed and extensive ecological research, which was not the main purpose of this study. Therefore, only the most valuable plant associations were assessed. Only the best-defined, direct and indirect impacts of climate change on the plant associations of the Biebrza Valley were considered. The preliminary assessment was based on the estimation of projected positive/ambiguous/negative (quantified as 1, 0 and -1 respectively) influences of climate and climate-inducedmanagement measures to habitats.

An expert knowledge- and literature-based review of plant associations' resilience to defined impacts revealed that valuable Natura 2000 associations such as Caricion davallianae, Caricion nigrae, Alopecurion pratensis and Molinion caeruleae (in general mire meadows) are among the most sensitive to the negative impacts of climate change in the Biebrza Valley. This is mostly due to the limitation of water as well as altered flooding in the summer, and due to the prospective spatial expansion of drainage. As some significant research on plant ecology in the Biebrza Valley with hydrological reference was already done (see e.g. Olde Venterink et al. 2009; Wassen et al. 1990), the presented expert-knowledge- and literaturebased preliminary impact assessment approach can be critically reviewed in a more detailed way for particular environmental elements of the Biebrza Valley, with a strong, site-specific context. Nevertheless, it appears that the adaptation of management strategies in the BNP should - as a priority - consider buffering potentially negative direct and indirect climate-change impacts to the contiguity and function of mires.

Indirect, negative, climate-related pressures on the ecosystems of the Biebrza Valley, such as drainage expansion, mowing cessation and meadow encroachment (see Table. 14.1), are clearly related to stakeholders' attitudes as to the climateinduced impacts. Therefore, it is likely that without appropriate stakeholder 
Table 14.1 Qualitative assessment of direct and indirect prospective climate-related impacts to selected plant associations in the Biebrza Valley

\begin{tabular}{|c|c|c|c|c|c|c|c|}
\hline \multirow[b]{2}{*}{$\begin{array}{c}\text { Selected plant } \\
\text { associations } \\
\text { of the Biebrza Valley }\end{array}$} & \multicolumn{2}{|c|}{$\begin{array}{l}\text { Climate-related } \\
\text { impacts to habitats }\end{array}$} & \multicolumn{3}{|c|}{$\begin{array}{l}\text { Climate change-related } \\
\text { stakeholder pressures } \\
\text { and habitat responses }\end{array}$} & \multirow[b]{2}{*}{ 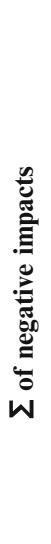 } & \multirow[b]{2}{*}{ 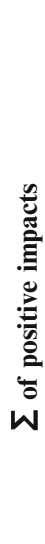 } \\
\hline & 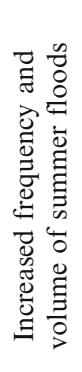 & 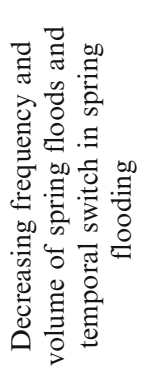 & 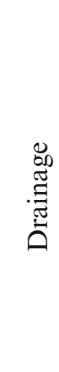 & 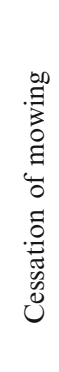 & 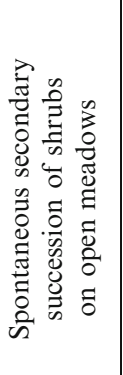 & & \\
\hline Bidention tripartite & 0 & 0 & -1 & 0 & 0 & $\mathbf{0}$ & $\mathbf{0}$ \\
\hline Alnion glutinosae & 1 & 1 & -1 & 0 & 0 & 1 & 2 \\
\hline Alnion glutinoso-incanae & 1 & 1 & -1 & 0 & 0 & 1 & 2 \\
\hline Alopecurion pratensis & -1 & -1 & -1 & -1 & 0 & 4 & $\mathbf{0}$ \\
\hline Arrhenatherion elatioris & 0 & 0 & 0 & -1 & -1 & 2 & $\mathbf{0}$ \\
\hline Betulo-Salicetum repentis & 0 & 0 & -1 & -1 & -1 & 3 & $\mathbf{0}$ \\
\hline Calthion & 0 & -1 & -1 & -1 & 0 & 3 & $\mathbf{0}$ \\
\hline Caricion davallianae & -1 & -1 & -1 & -1 & -1 & 5 & $\mathbf{0}$ \\
\hline Caricion lasiocarpae & 0 & 0 & -1 & -1 & -1 & 3 & $\mathbf{0}$ \\
\hline Caricion nigrae & -1 & -1 & -1 & -1 & -1 & 5 & $\mathbf{0}$ \\
\hline Carpinion betuli & 0 & 0 & 0 & 0 & 0 & 0 & $\mathbf{0}$ \\
\hline Corynephorion canescentis & 0 & 0 & 0 & 0 & -1 & 1 & 1 \\
\hline Dicrano-Pinion & 0 & 0 & 0 & 0 & 0 & $\mathbf{0}$ & $\mathbf{0}$ \\
\hline Filipendulion ulmariae & 0 & -1 & -1 & 0 & 1 & 2 & 1 \\
\hline Koelerion glaucae & 0 & 0 & 0 & -1 & -1 & 2 & $\mathbf{0}$ \\
\hline Magnocaricion & 0 & -1 & -1 & -1 & 0 & 3 & $\mathbf{0}$ \\
\hline Molinion caeruleae & 0 & -1 & -1 & -1 & -1 & 4 & $\mathbf{0}$ \\
\hline Phragmition & 1 & 0 & -1 & 0 & 0 & 1 & 1 \\
\hline Polio-Callunion & 0 & 0 & 0 & 0 & -1 & 1 & 1 \\
\hline Potentillo albae-Quercion & 0 & 0 & 0 & 0 & 0 & $\mathbf{0}$ & $\mathbf{0}$ \\
\hline Salicetum pentandro-cinereae & 0 & 0 & -1 & 0 & 0 & 1 & 1 \\
\hline Spraganio-Glycerion & 0 & 0 & -1 & 0 & 0 & 1 & 1 \\
\hline Vacc.uliginosi-Betul. pubesc. & 0 & 0 & -1 & 0 & 0 & 1 & 1 \\
\hline Violion caninae & 0 & 0 & 0 & 0 & -1 & 1 & 1 \\
\hline
\end{tabular}

1 - positive impact, 0 - ambiguous impact, -1 - negative impact. Only the "extreme" climate scenario for the Biebrza Valley was considered possible, the most challenging for ecosystem management. Associations of the most significant negative response are marked grey

communication, climate-adapted management of any kind will fail to effectively achieve its environmental goals (Lee 1991). Environmental conservation especially in situations where a vast share of the protected area remains private (such as in the BNP) - requires the identification of stakeholders and the adjustment 


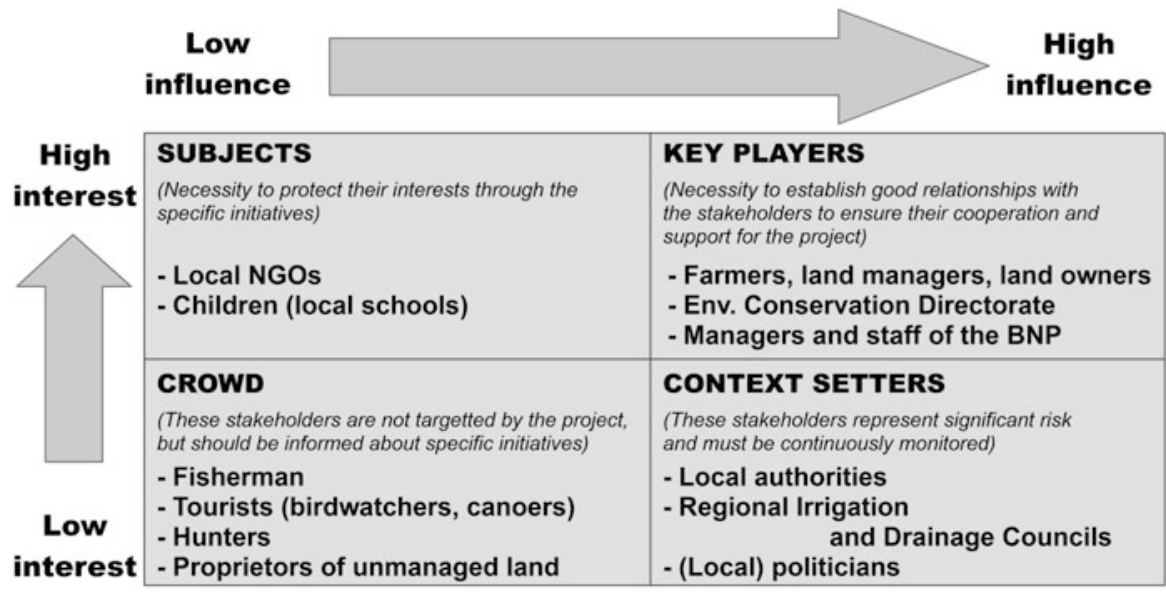

Fig. 14.4 Stakeholder classification matrix - case study of stakeholder dialogue on valuable and protected wetlands management in the Biebrza Valley (Boumrane 2007, after Zarzo Fuertes et al. 2011, modified)

of communication strategies to achieve the goals of ecological sustainability conservation. In this regard, stakeholders in environmental management in the BNP were identified and grouped in order to define their importance and establish appropriate dialogue (Fig. 14.4).

It is likely that appropriate stakeholders' information about the measures that they plan to apply (e.g. long-term strategies for mowing, participation in environmental schemes, change in the type of land use) can be included in impact-assessment and ecosystem response analysis with the use of modelling tools (e.g. Wassen et al. 2011). Such an approach would become an integrated feedback assessment tool for the climate change - stakeholder reaction and environmental response.

Four groups with different levels of interest and influence were identified: key players, context setters, subjects and the crowd (Fig. 14.4). Among the stakeholders, which were defined as the "key players" in the adaptive management process in BNP, there are farmers, land owners, land managers and the Regional Environmental Conservation Directorate (RECD) (Pol.: Regionalna Dyrekcja Ochrony Środowiska). In case of the most challenging discussed "extreme" scenario of climate change in 2070-2100, the most critical reaction of those groups is expected due to their legislative context. Farmers, land owners and land managers, all substantially benefitting from the presence of the unique habitats on their land (by obtaining EU environmental subsidies for rare species such as Acrocephalus paludicola and Crex crex), are expected to increase their pressure to drain the Biebrza mires as those measures are subsidised. In this regard, the RECD, as the key player responsible for management measures approval on Natura 2000 sites, will face the appropriate environmental evaluation of prospective initiatives, such as drainage. However, the utmost challenge in this process will be to deal with valuable habitats threatened by the same, direct climate change impacts as for the agriculture. The discussed, possible 
increase in the frequency of summer flooding can be given as an exemplary challenge for both agriculture and habitats, being equally negative for ecological function of particular habitats (Caricion davallianae and Molinion caeruleae) as well as for the agricultural use of wetlands (mowing will be impossible due to the high water level). This problem, already faced by the environmental management authorities in NE Poland, has to be widely-discussed and analysed in a broader context. Hence, the feedback from the other stakeholders should be obtained (e.g. local authorities, local NGO's and tourists), in order to set up the clear criteria for adaptive decision making and to minimise the negative influences of climate change on the ecosystems. It should be stated herein that some positive results from stakeholder dialogue conducted for numerous years in the form of environmental education in schools in the Biebrza Valley, supervised by the BNP, have already been obtained. The perception of environmental goals in the hierarchy of aspects remains positive in the group of children among the inhabitants of the Biebrza Valley. Despite that, still further emphasis has to be placed on climate change-related challenges for wetlands and management in the Biebrza Valley in environmental education.

Experience, which we obtained in the BNP in regard to stakeholder communication, allows the conclusion that climate change itself is often opposed, if not referred to a phenomena experienced by people. Moreover, climate change is often considered as a global problem and thus not relevant as a local challenge. Therefore, if in the stakeholder's perception climate change is denied, any further steps aimed at management adaptation and measure proposal fails to become successful from the very beginning of the process. It is worth noting that the effects of (changing) climate on the environment and agriculture continue to be denied, even among the environmental managers in the study area. Such a status is also assumed to occur worldwide, within the other protected areas. Therefore, despite the variability of levels in stakeholder classification and stakeholder's environmental consciousness, climate-related pressures to management and ecosystems has to be emphasised and communicated more and more efficiently.

\subsubsection{Criteria of Climate-Adapted Wetland Management in the Biebrza Valley}

Once the background and contexts of adaptive management in the Biebrza Valley are preliminarily revealed (Sects. 14.3.1, 14.3.2 and 14.4.1, 14.4.2, 14.4.3), contemporary management measures (generalised, after Minister of Environment 2011) are evaluated in order to indicate potential opportunities for management adaptation (Table 14.2).

As revealed by Grumbine (1994), Kadoya and Washitani (2007) and Lee (1991), management adaptation should continuously refer to the current status of ecosystems and species. Therefore, on top of impact assessment and stakeholder feedback, the well-established monitoring of the efficiency of the applied measures should become an inherent element of adaptive decision making. Due to the various 
Table 14.2 Selected management measures applied by the Biebrza National Park, to be considered and adjusted in adaptive ecosystem management

\begin{tabular}{|c|c|c|c|}
\hline No. & Management measure & Climate-induced challenges & $\begin{array}{l}\text { Monitoring-based adaptation } \\
\text { criteria }\end{array}$ \\
\hline 1. & $\begin{array}{l}\text { Strict protection of } \\
\text { valuable ecosystems }\end{array}$ & $\begin{array}{l}\text { Change in abiotic factors (alter- } \\
\text { ation of water level and tem- } \\
\text { perature) can induce generic } \\
\text { deterioration of protected } \\
\text { habitats; shift in species }\end{array}$ & $\begin{array}{l}\text { Monitoring of ecosystem status and } \\
\text { species composition (change the } \\
\text { boundaries of strict protection/ } \\
\text { switch to active protection); } \\
\text { monitoring of plots with no } \\
\text { management measures applied; }\end{array}$ \\
\hline 2. & $\begin{array}{r}\text { Active protection of } \\
\text { selected habitats }\end{array}$ & $\begin{array}{l}\text { Change in abiotic factors (alter- } \\
\text { ation of water level and tem- } \\
\text { perature) can induce generic } \\
\text { deterioration of protected } \\
\text { habitats; shift in species }\end{array}$ & $\begin{array}{l}\text { Monitoring of ecosystem status } \\
\text { and species composition } \\
\text { (change the boundaries of } \\
\text { active protection/switch to } \\
\text { landscape protection); } \\
\text { monitoring of plots with } \\
\text { no management applied } \\
\text { (e.g. similar habitats mown } \\
\text { and unmanaged) }\end{array}$ \\
\hline 3. & $\begin{array}{r}\text { Invasive species } \\
\text { management }\end{array}$ & $\begin{array}{l}\text { New invasive species can occur, } \\
\text { which can be even more com- } \\
\text { petitive to native species than } \\
\text { those already defined }\end{array}$ & $\begin{array}{l}\text { Reduction in invasive species } \\
\text { populations, ecological moni- } \\
\text { toring, habitat monitoring }\end{array}$ \\
\hline 4. & $\begin{array}{l}\text { Purchase of private } \\
\text { grounds within the } \\
\text { boundaries of the } \\
\text { Biebrza National Park }\end{array}$ & $\begin{array}{l}\text { More frequent summer flooding } \\
\text { can encourage land proprie- } \\
\text { tors that it is more feasible to } \\
\text { sell certain portions of their } \\
\text { land; possible reduction of } \\
\text { price per hectare }\end{array}$ & $\begin{array}{l}\text { Continuous and well established } \\
\text { stakeholder dialogue, ground } \\
\text { purchase strategies flexible to } \\
\text { dynamic habitat distribution }\end{array}$ \\
\hline 5. & $\begin{array}{l}\text { Increase in bird popula- } \\
\text { tion density by } \\
\text { meadow mowing and } \\
\text { biomass removal }\end{array}$ & $\begin{array}{l}\text { Summer flooding can limit the } \\
\text { abilities of mowing and bio- } \\
\text { mass removal; possible fluc- } \\
\text { tuations in bird species } \\
\text { populations regardless of } \\
\text { applied management } \\
\text { measures }\end{array}$ & $\begin{array}{l}\text { Monitoring of bird population in a } \\
\text { trans-national context, } \\
\text { site-specific flexible adjust- } \\
\text { ment of areas to be mowed }\end{array}$ \\
\hline 6. & $\begin{array}{l}\text { Reduction in shooting of } \\
\text { wild boar, racoon dog } \\
\text { and fox }\end{array}$ & $\begin{array}{l}\text { Possible shift in animal habitats } \\
\text { and population density }\end{array}$ & $\begin{array}{l}\text { Feedback with local hunting } \\
\text { associations as to contempo- } \\
\text { rary reduction in shooting and } \\
\text { game species population } \\
\text { dynamics }\end{array}$ \\
\hline 7. & $\begin{array}{l}\text { Hydrographic network } \\
\text { restoration (Rivers } \\
\text { Jegrznia and Ełk) }\end{array}$ & $\begin{array}{l}\text { Possible change in discharge } \\
\text { regime of rivers can influence } \\
\text { water management and nega- } \\
\text { tively affect flood control; } \\
\text { possible conflicts and increase } \\
\text { in drainage pressure }\end{array}$ & $\begin{array}{l}\text { Continuous hydrological moni- } \\
\text { toring and stakeholder dia- } \\
\text { logue; continuous feedback } \\
\text { from farmers, land owners and } \\
\text { land proprietors }\end{array}$ \\
\hline 8. & $\begin{array}{l}\text { Open meadow mainte- } \\
\text { nance by pasture } \\
\text { grazing (Polish konik } \\
\text { horses) }\end{array}$ & $\begin{array}{l}\text { High groundwater levels can limit } \\
\text { grazing and meadow produc- } \\
\text { tivity; dry summers can peri- } \\
\text { odically increase meadow } \\
\text { productivity (enhancement in } \\
\text { biogeochemical changes of } \\
\text { the peat) }\end{array}$ & $\begin{array}{l}\text { Control of Polish konik popula- } \\
\text { tion; control of grazing inten- } \\
\text { sity, flexibility in pastures } \\
\text { delineation }\end{array}$ \\
\hline
\end{tabular}

Based on Minister of Environment (2011) 
potential responses of habitats and species to both management measures and climate-related impacts (e.g. Table 14.1.), each of the defined challenges for the environment of the Biebrza Valley and the stakeholders should be taken into consideration in the broad context of internal and external threats.

Despite the fact that the MOs are renewed every 2 years, the review of those documents revealed that not much attention is paid to any form of climate-proof management adaptation in the BNP. Neither the dynamic status of ecosystems nor climate changes were so far defined as threats to the ecosystems of the Biebrza Valley. In the long-term, more flexibility is needed in establishing management measures such as invasive species management, mowing, biomass removal and pasture grazing. It is likely that the contemporary setup of strictly/actively protected areas, which is not critically reviewed on the basis of habitat monitoring and species composition, will fail to fulfil sustainable environmental conservation requirements. The transient character of physical processes induced by climate as well as ecosystem dynamics can result in the deterioration of environmental values. In habitats of the most climate-change sensitive plant associations (Caricion davallianae, Caricion nigrae, Alopecurion pratensis and Molinion caeruleae), the lack of flexibility in management implementation is likely to induce habitat deterioration by the overexploitation of certain vegetation patches by mowing, or by the cessation of mowing in wetter conditions. Hence, the establishment of an effective "monitoring-decision making" feedback tool is needed in order to prevent negative management influences on the environment. As such, some decision support tools were already proposed for the Biebrza Valley (Chormański et al. 2009; Kardel et al. 2011). However, further interactive and practice-orientated approaches should be developed in order to manage climate-induced impacts on stakeholders and ecosystems. Even though the climate change influence on the Biebrza Wetlands was not so far revealed in detail, a knowledge base and scientific support regarding the hydrology and ecology of the Biebrza Valley is rich and can be successfully applied in wetland adaptive management.

Despite the intensified monitoring of ecosystems and their species composition, further functional assessment is required in order to analyse the continuous feedbacks between the ecosystem status, response to management and resilience to climate change. It is certain that when facing the climate-related pressures, certain ecosystems will require newly developed measures. Contradictorily, it is likely that some other ecosystems will not require any active management measures as they will either evolve into the new ecosystems, adapted to the changing conditions, or the new (climate) conditions will be sufficient in order to maintain the ecosystem in an appropriate ecological status. Therefore, the adaptive management should require extensive ecosystem monitoring in which both the "managed" and "unmanaged" ecosystems will be critically reviewed as to the (1) efficiency of the applied measures in order to conserve the nature, (2) influence of climate and ecosystem evolution processes on the habitat with no measures applied, and (3) possibility of new measures development and application, which will be adjusted to possible climate influences and accepted by the managers and stakeholders. The iterative, management-response feedback loops (Fig. 14.5) should therefore 


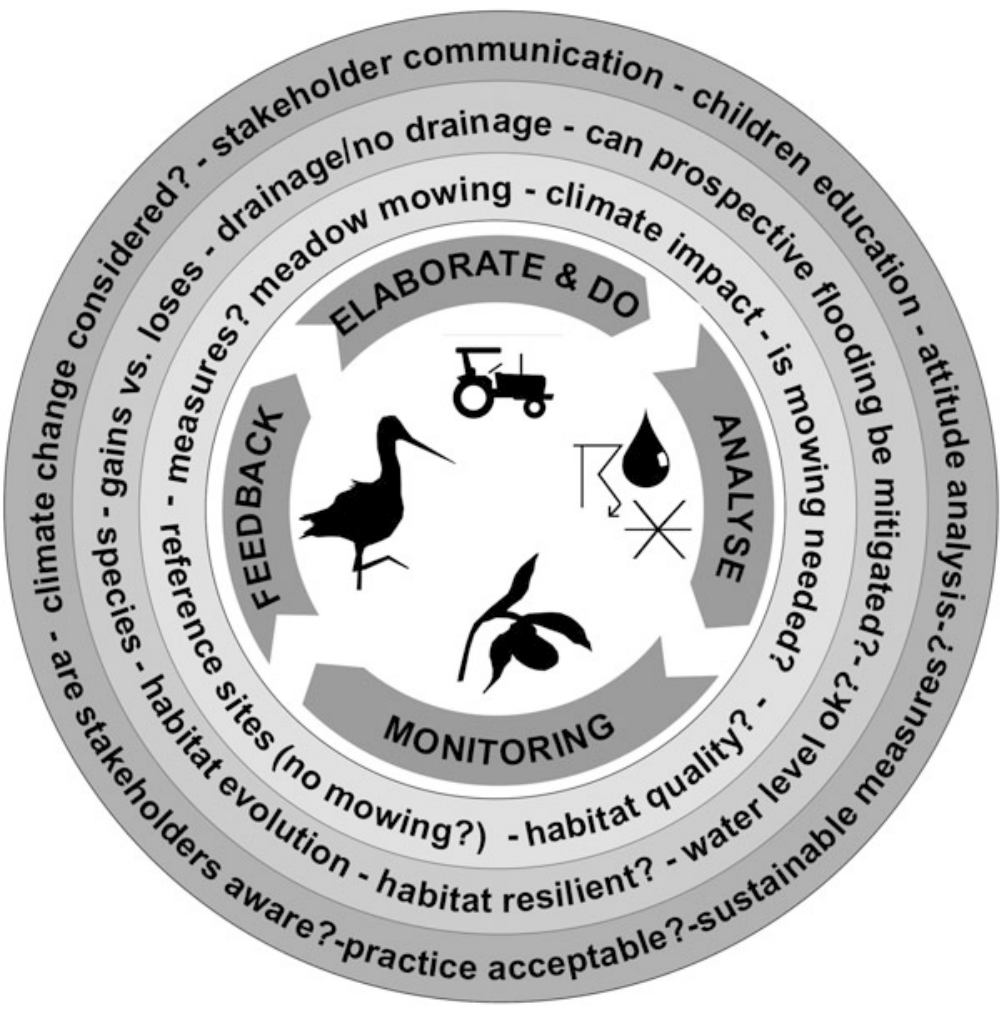

Fig. 14.5 Three levels of adaptive climate-proof wetland management: feedback on direct climate change impacts to habitats (e.g. is meadow mowing needed?), feedback on climatedriven-human enforced impact to habitats (e.g. drainage of wetlands - gain or loss?) and the stakeholder communication process (what, how and who to communicate?)

contain the analysis of three possible levels of complexity: climate-ecosystems, climate-management-ecosystems and climate-communication-management-ecosystems.

In the case of Biebrza Valley it is likely that some plant alliances facing the climate change influences (e.g. Caricion nigrae and Molinion caeruleae), such as increasing water levels, will no longer require mowing (ref. to Tables 14.1 and 14.2) as the secondary succession of encroachments will be naturally limited. Management flexibility based on direct, site-orientated monitoring should allow the decision to be made in such examples. Also the technical and relatively invasive measures of ecosystem restoration (such as blocking ditches, topsoil removal) should in this regard be monitored and referred to observed and projected climate change responses. It can appear that the natural evolution of ecosystems influenced by climate (e.g. higher hydration of soil due to higher precipitation and reduced draining influence of rivers and canals to adjacent wetlands due to higher water levels in the summer induced by short but heavy rainfalls projected for the future 
within the Biebrza Valley) is likely to evoke similar "restoration" processes that the undertaken technical measures. Furthermore, the continuous monitoring of stakeholder's consciousness and attitudes (indicated in the outermost ring in Fig. 14.5) will allow the selection and application of the best strategies for communication in order to sustain appropriate, climate-proof adaptive environmental management in the Biebrza Valley.

\subsection{Conclusions}

With no regard to the uncertainty of the GCM-RCM-emission scenarios-based climate change projections, the management of the BNP should implement climate-adapted management strategies which consider the range of various prospective climate impact projections. Strategies should anticipate the potential increase in summer flooding frequency, temporal and quantitative changes in spring flooding as well as indirect, climate-induced pressures on ecosystems, herein defined as the potential escalation of drainage in the valley and also as the secondary succession of trees and shrubs in mire meadows.

Since following the reports of Kossowska-Cezak (1984) and Kossowska-Cezak et al. (1991), the climate of the Biebrza Valley was not analysed in detail, it is essential to revisit their results on the basis of observations over the last 20 years. Such research would critically reveal the long-term changes in multiple elements of the climate and could become a comprehensive baseline for the establishment of climate change scenarios and their impacts on the ecosystems of the Biebrza Valley.

All the contemporary environmental management measures implemented so far by the BNP and local stakeholders are likely to be affected by the observed/ prospective climate change.

The most negative prospective climate scenario for the Biebrza Valley in the time horizon 2070-2100 assumes a significant increase in precipitation in summer (which will result in an increased frequency of summer flooding), a decrease in precipitation in autumn, winter and spring (which will induce a reduction in spring flooding and underpin the hydrological stress on wetland vegetation at the start of the growing season) and a general increase in the average air temperature (which will induce an increase in potential evapotranspiration in the summer and reduction of snow accumulation in the winter).

Climate change impacts to wetlands can be defined as direct (climate change influences the environment: less rain - less flooding - habitats induced) and indirect (climate change entails the reaction of managers and stakeholders, which consequently induce habitats: more rain - flooding mitigated by the drainage - declining groundwater levels challenge the wetlands). Both levels of impacts should be anticipated in climate-adapted environmental management.

Plant associations such as Caricion davallianae, Caricion nigrae, Alopecurion pratensis and Molinion caeruleae, are suspected to be among the most sensitive to negative impacts of climate change in the Biebrza Valley. While for certain habitats 
projected impacts of climate change are positive, for others they seem to remain negative (e.g. increased frequency of summer flooding: positive for Phragmition, negative for Caricion davalianae).

If the hydrological impacts of climate change remained continuing the trends observed in 1951-2009, reactions of stakeholders (mostly farmers and land owners) will induce indirect, but still climate-related pressures to ecosystems, among which the most important and the most negative to wetlands seems to be the drainage.

In the case of numerous management measures, which have so far been successfully implemented in the BNP (hydrographic network restoration, purchase of private grounds), the enhanced establishment of stakeholder dialogue is necessary in order (1) to underline the awareness of climate change impacts to the management and (2) to obtain appropriate feedback - a key to successful management adaptation. Observing the attitudes of stakeholders we state, that still more emphasis should be put in order to present the climate change as a local problem than - as so far considered - a global undefined phenomenon.

More spatial flexibility is needed when setting up both short- and long-term management measures on wetlands in the Biebrza Valley, especially due to meadow mowing and the establishment of strict and active protection. It is likely that the contemporary management measures will lose their conservation efficiency if the continuous feedback of direct climate influences, indirect climate influences (by changing management) and natural evolution of ecosystems was not considered in environmental management on wetlands in general, and in the Biebrza Valley in particular. Adaptive approaches in environmental management of wetlands (and the Biebrza Valley in particular) should be aimed at (1) continuous and extensive monitoring of management measures efficiency along with (2) analysis of reference, unmanaged sites dynamics. Once the climate impacts were defined in positive feedbacks to ecosystem status, management measures such as meadow mowing should be critically reviewed as to their ecological efficiency.

Facing the presented results we conclude that any prospective, long-term conservation and maintenance strategies, which are planned to be implemented in valuable wetlands with no particular regard to possible direct and indirect climate-induced alterations on hydrological processes, will fail to fulfil the requirements of sustainable ecosystem management.

Acknowledgements The presented study was funded by the project 2CE168P3 HABITCHANGE - Adaptive management of climate-induced changes of habitat diversity in protected areas, implemented through the E.U. Central Europe Programme, co-financed by the European Regional Development Fund. The authors gratefully thank Michał Fabiszewski, Andrzej Grygoruk, Grzegorz Kwiatkowski, Robert Makuła, Adam Szarnecki, Danuta Zawadzka and Marek Żdanuk from Biebrza National Park for an outstanding contribution to data collection and processing, as well as for the successful project implementation. Field services of the Biebrza National Park are acknowledged for their continuous and detailed monitoring of the hydrological and meteorological processes. HABIT-CHANGE project partners are acknowledged for the effective cooperation in project implementation. Reviewers are acknowledged for their thoughtful comments which helped improve this manuscript. 
Open Access This chapter is distributed under the terms of the Creative Commons Attribution Noncommercial License, which permits any noncommercial use, distribution, and reproduction in any medium, provided the original author(s) and source are credited.

\section{References}

Acreman, M. C. (2012). Wetlands and water storage: Current and future trends and issues (Ramsar scientific and technical briefing note No. 2). Gland: Ramsar Convention Secretariat.

Anagnostopoulos, G. G., Koutsoyiannis, D., Christofides, A., Efstratiadis, A., \& Mamassis, N. (2010). A comparison of local and aggregated climate model outputs with observed data. Hydrological Sciences Journal, 55, 1094-1110.

Banaszuk, H. (Ed.). (2004). Biebrza Valley and Biebrza National Park. Białystok: Wydawnictwo Ekonomia i Środowisko.

Boumrane, M. (2007). Dialogue in biosphere reserves: References, practices and experiences (Biosphere reserves - Technical notes 2). Paris: UNESCO.

Chormański, J., Kardel, I., Świątek, D., Grygoruk, M., \& Okruszko, T. (2009). Management support system for wetlands protection: Red Bog and Lower Biebrza Valley case study. IAHS Publications, 331, 423-431.

Grumbine, R. E. (1994). What is ecosystem management? Conservation Biology, 8, 27-38.

Grygoruk, M., Batelaan, O., Okruszko, T., Mirosław-Świątek, D., Chormański, J., Chormański, J., \& Rycharski, M. (2011a). Groundwater modelling and hydrological system analysis of wetlands in the Middle Biebrza Basin. In T. Okruszko \& D. Swiatek (Eds.), Modelling of hydrological processes in the Narew Catchment (GeoPlanet: Earth and planetary sciences series, pp. 89-109). Berlin/Heidelberg: Springer.

Grygoruk, M., Mirosław-Świątek, D., Kardel, I., Okruszko, T., Michałowski, R., \& Kwiatkowski, G. (2011b). Analysis of past-present hydrological phenomena of the Biebrza Valley (Report 4.4.2). HABIT-CHANGE, $29 \mathrm{pp}$.

Hardig, E. K., Grozev, O., \& Rosenzweig, C. (1997). Climate change, agriculture and wetlands in Eastern Europe: Vulnerability, adaptation and policy. Climatic Change, 36, 107-121.

Ignar, S., Maksymiuk-Dziuban, A., Mirosław-Świątek, D., Chormański, J., Okruszko, T., \& Wysocki, P. (2011). Temporal variability of selected flood parameters in the Biebrza River valley. Annals of Warsaw University of Life Sciences - SGGW, 43, 135-142.

Kadoya, T., \& Washitani, I. (2007). An adaptive management scheme for wetland restoration incorporating participatory monitoring into scientific predictions using dragonflies as an indicator taxon. Global Environmental Research, 11, 179-185.

Kardel, I., Chormański, J., Mirosław-Świạtek, D., Okruszko, T., Grygoruk, M., \& Wassen, M. (2011). Decision support system for Biebrza National Park. In Jao, C. (ed.), Efficient decision support systems: Practice and challenges - From current to future (Book 1. InTech). ISBN: 978-953-308-65-7, doi: 10.5772/682

Keddy, P. A. (2010). Wetland ecology - Principles and conservation. Cambridge: Cambridge University Press.

Kossowska-Cezak, U. (1984). Climate of the Biebrza ice-marginal valley. Polish Ecological Studies, 10(3-4), 253-279.

Kossowska-Cezak, U., Olszewski, K., \& Przybylska, G. (1991). Climate of the Biebrza Valley (in Polish). Zeszyty Problemowe Postepów Nauk Rolniczych, 372, 119-158.

Kundzewicz, Z. W., \& Stakhiv, E. Z. (2010). Are climate models "ready for prime time" in water resources management applications, or is more research needed? Hydrological Sciences Journal, 55, 1085-1089.

Lee, K. N. (1991). Appraising adaptive management. Conservation Ecology, 3. URL: http://www. consecol.org/vol3/iss2/art3. Accessed 12 July 2012. 
Liszewska, M., \& Osuch, M. (2000). Analysis of results of global climate models for Central Europe and Poland. Geographia Polonica, 73, 49-63.

Maksymiuk, A. (2009). Time variability of the selected environmental factors in the Biebrza River Basin (in Polish). PhD. thesis, Warsaw University of Life Sciences.

Maksymiuk, A., Furmańczyk, K., Ignar, S., Krupa, J., \& Okruszko, T. (2008). Analysis of climatic and hydrologic parameters variability in the Biebrza River basin. Przeglad Naukowy Inzynieria i Ksztattowanie Środowiska, 3, 69-77.

Maltby, E. (2009). Functional assessment of wetlands: Towards evaluation of ecosystem services. Cambridge: Woodhead Publishers. $672 \mathrm{pp}$.

Minister of the Environment. (2011). Decree of management objectives for the Biebrza National Park (Decree No. 3, dated 17th January 2011). Ministry of the Environment of Poland.

Okruszko, H. (1991). Wetland types in Biebrza Valley (in Polish). Zeszyty Problemowe Postepów Nauk Rolniczych, 372, 163-184.

Okruszko, T., Duel, H., Acreman, M., Grygoruk, M., Flörke, M., \& Schneider, C. (2011). Broad scale ecosystem services of European wetlands - Overview of the current situation and future perspectives under different climate and water management scenarios. Hydrological Sciences Journal, 53, 1501-1517.

Olde, V. H., Kardel, I., Kotowski, W., Peeters, W., \& Wassen, M. J. (2009). Long-term effects of drainage and hay-removal on nutrient limitation in the Biebrza mires, Poland. Biogeochemistry, 93, 235-252.

Oświt, J. (1991). Structure, genesis and development of peatlands in the Biebrza Valley (in Polish). Zeszyty Problemowe Postepów Nauk Rolniczych, 185-217.

Petermann, J., Balzer, S., Ellwanger, G., Schröder, E., \& Ssymank, A. (2007). Klimawandel Herausforderung für das europaweite Schutzgebietssystem Natura 2000. Naturschutz und Biologische Vielfalt, 46, 127-148.

Piniewski, M., Laizé, C. L. R., Acreman, M. C., Okruszko, T., \& Schneider, C. (2012). Effect of climate change on environmental flow indicators in the Narew Basin, Poland. Journal of Environmental Quality. doi:10.2135/jeq2011.0386.

Polakowski, M., Broniszewska, M., Jankowiak, Ł., Ławicki, Ł., \& Siuchno, M. (2011). Numbers and dynamics of spring migration of geese in the Biebrza Basin. Ornis Polonica, 52, 169-180.

Schneider, C., Flörke, M., Geerling, G., Duel, H., Grygoruk, M., \& Okruszko, T. (2011). The future of European floodplain wetlands under a changing climate. Journal of Water and Climate Change, 2, 106-122.

Stagl, J. \& Hattermann, F. (2011). Climate change impacts as a boundary conditions; Hydrological features of selected areas (Technical Reports 3.2 .3 and 3.2.7). HABIT-CHANGE, 55 pp. URL: http://habit-change.eu/fileadmin/Dateisammlung/files/Outputs/HABIT-CHANGE_3_ 2_3_3_2_7_climate_trends_and_impacts_on_hydrological_features.pdf

Wagner, I. \& Förster, M. (2011). Climate change indicator classification tool (Technical Report 4.2.1a). HABIT-CHANGE, 18 pp. URL: http://131.130.59.133/projekte/HABIT-CHANGE/ download_tool.cfm

Wall, G. (1998). Implications of global climate change for tourism and recreation on wetland areas. Climatic change, 40, 371-389.

Wassen, M. J., Barendregt, A., Pałczyński, A., de Smidt, J. T., \& de Mars, H. (1990). The relationship between fen vegetation gradients, groundwater flow and flooding in an undrained valley mire at Biebrza, Poland. Journal of Ecology, 78, 1106-1122.

Wassen, M. J., Bleuten, W., \& Bootsma, M. C. (2002). Biebrza as geographical reference. Annals of Warsaw Agriculture University, Land Reclamation, 33, 27-47.

Wassen, M. J., Okruszko, T., Kardel, I., Chormański, J., Świątek, D., Mioduszewski, W., Bleuten, W., Querner, E. P., El Kahloun, M., Batelaan, O., \& Meire, P. (2006). Eco-hydrological functioning of the Biebrza Wetlands: Lessons for the conservation and restoration of deteriorated wetlands. In R. Bobbink, B. Beltman, J. T. A. Verhoeven, \& D. F. Wigham (Eds.), Wetlands: Functioning, biodiversity conservation and restoration (pp. 285-310). Berlin/Heidelberg: Springer.

Wassen, M. J., Runhaar, H. A. C., Barendregt, A., \& Okruszko, T. (2011). Evaluating the role of participation in modelling studies for environmental planning. Environment and Planning B: Planning and Design, 38, 338-358. 
Wilby, R. L. (2005). Uncertainty in water resource model parameters used for climate change impact assessment. Hydrological Processes, 19, 3201-3219.

Wilby, R. L. (2010). Evaluating climate model outputs for hydrological applications - Opinion. Hydrological Sciences Journal, 55, 1090-1093.

Winter, T. C. (2000). The vulnerability of wetlands to climate change: A hydrologic landscape perspective. Journal of the American Water Resources Association, 32, 305-311.

Zarzo Fuertes, O., Heiland, S., Rannow, S., \& Wilke, C. (2011). Stakeholder involvement in CAMPs A handbook (Technical Report 5.3.2A). HABIT-CHANGE, 27 pp. URL: http://habit-change.eu/ fileadmin/Dateisammlung/files/Outputs/HABIT-CHANGE_Stakeholder_Involvement_Hand book_2011-12-05.pdf

Żurek, S. (1984). Relief, geologic structure and hydrography of the Biebrza Valley. Polish Ecological Studies, 10, 239-259. 